\title{
BUDAYA POP DARI KOREA DAN DAMPAKNYA DI INDONESIA
}

\author{
Oleh Muhammad Daud Yusuf \\ muhammad.dy@gmail.com
}

\begin{abstract}
Abstrak
Sejalan perkembangan zaman perubahan pada budaya pop, membuat definisi budaya pop semakin kompleks. Menurut Burton (2019), budaya didominasi oleh produksi dan konsumsi barang-barang material dan bukan oleh seni-seni sejati, manakala peroduksinya didorong oleh orientasi laba (profit oriented).Budaya pop merupakan dialektis antara hegemonis atau penyeragaman dengan heterogenis atau keragaman. Dr.Ibrahim (2017),menyatakan bahwa budaya yang disokong industri budaya telah mengkonstruksi masyarakat yang tidak sekedar berlandaskan konsumsi, tetapi juga menjadikan artefak budaya sebagai produk industri dan sudah tentunya komoditi.Budaya pop berkaitan dengan budaya massa. Budaya massa adalah budaya populer yang dihasilkan melalui teknik-teknik industrial produksi massa dan dipasarkan untuk mendapatkan keuntungan dari khalayak yakni konsumen massa. Budaya massa ini berkembang sebagai akibat dari kemudahankemudahan reproduksi yang diberikan oleh teknologi seperti mesin percetakan, fotografi, perekaman suara, dan sebagainya (Malthy via Tressia: 20: 37). Horkheimer \& Adorno (2009), menyatakan bahwa budaya kini sepenuhnya saling berpautan dengan ekonomi, politik dan produksi budaya oleh kapitalis.
\end{abstract}

Kata Kunci:Budaya-dialektis-konsumsi dan massa

\section{Latar Belakang Penelitian}

Budaya bisa populer dan mendunia melalui siaran media massa, seperti televisi dan surat kabar serta majalah, sebagai bagian dari proses kapitalisme. Budaya-budaya yang populer tersebut tidak jarang pula menggerus budaya lokal (local wisdom) yang ada. Produk budaya juga sangat berpengaruh terhadap masyarakat, seperti permainan tradisional yang kian hari semakin habis peminatnya,beralih kepada permainan yang bersifat online. Padahal hal tersebut bisa menghilangkan identitas budaya lokal tertentu yang aslinya. 
Namun, perlu diketahui bahwa budaya pop tidak selamanya berdampak negatif. Dibalik semua itu akan kita dapati dampak-dampak positifnya. Semua itu kembali lagi kepada kita semua, bagaimana cara kita bisa menyikapinya.

\section{Kajian Pustaka}

\subsection{Budaya Pop}

Budaya pop disebut pula sebagai budaya populer atau kultur populer yakni totalitas ide, perspektif, perilaku, meme, citra, dan fenomena lainnya dipilih oleh konsensus informal di dalam arus utama sebuah budaya, khususnya oleh budaya barat di awal hingga pertengahan abad ke-XX. Dan arus utama globalisasi yang muncul pada akhir abad ke-XX dan awal abad ke-XXI. Dengan pengaruh besar sebaran dari media massa, kumpulan ide ini menembus kepada kehidupan masyarakat global sehingga menjadi populer.

Budaya pop dinilai sebagai sesuatu hal yang sepele dalam rangka mencari penerimaan konsensual melalui arus utama globalisasi informasi. Akibatnya, budaya pop muncul dari balik kritisisme sengit dari berbagai sumber non arus utama khususnya kelompok-kelompok agamawan dan kelompok kontra budaya yang menilik hal ini sebagai superfisial, konsumeris, sensasionalis, dan rusak, menampakan hubbudunya.

Paham Budaya pop muncul abad ke-XIX merujuk pada pendidikan dan "culturedness" pada kaum bawah. Istilah tersebut mulai menganggap pengertian budaya kelas bawah terpisah dan terkadang bertentangan dengan pendidikan sejati menuju akhir abad, penggunaannya kemudian menjadi mapan ketika periode antar perang. Pengertiannya pada saat ini istilah tersebut bahwa budaya, untuk konsumsi masyarakat, khususnya berawal di Amerika Serikat, yang digunakan pada akhir Perang Dunia II. Budaya pop bermula tahun 1960-an. 
Budaya pop mulanya berkembang di Eropa, lebih banyak diasumsikan dengan budaya yang melekat pada kaum awam bawah, yang membedakannya dengan budaya tinggi dari kelas elit. Budaya pop juga sering di istilahkan dengan mass culture atau budaya massa, dibuat secara masal dan dikonsumsi secara masal pula.

Budaya Pop asal katanya yakni dari "Budaya" dan "Pop". Menurut Kamus Besar Bahasa Indonesia (KBBI), Budaya adalah (1) pikiran; akal budi, (2) adat istiadat, (3) sesuatu mengenai kebudayaan yang sudah berkembang atau beradab atau maju, (4) sesuatu yang sudah menjadi kebiasaan serta yang sudah sukar diubah.Budaya juga diartikan sebagai cara manusia memberikan respon kepada lingkungannya, agar dia bisa survive serta menang dalam kompetisi kehidupan. Kata "Pop" berasal dari kata "Populer" dalam KBBI diartikan sebagai sesuatu yang dikenal dan disukai orang banyak secara umum atau masal, sesuai dengan kebutuhan massa; mudah dipahami orang banyak, disukai dan dikagumi orang banyak.Budaya pop dapat pula diasumsikan sebagai sesuatu yang sudah berkembang kemudian menjadi kebiasaan dan disukai oleh banyak orang.

Menurut Stuart Hall bahwa budaya pop sebagai "sebuah arena konsensus dan resistensi. Budaya pop merupakan tempat munculnya hegemoni, dan wilayahnya ditempat hegemoni berlangsung. Ia bukan ranah dimana sosialisme, sebuah kultur sosialis yang telah terbentuk sepenuhnya dapat sungguh-sungguh diperhatikan. Namun, ia adalah salah satu tempat dimana sosialisme boleh jadi diberi legalitas. Itulah mengapa 'budaya pop' menjadi sesuatu yang penting.

\subsection{Macam-macam Bentuk Budaya Pop}

Budaya pop merupakan dialektika antara hegemonisasi atau penyeragaman dengan heterogenisasi atau keragaman. Konsep keragaman atau heterogenisasi dalam budaya pop juga terdapat dua bagian terpisah dalam budaya pop, yakni: Pertama, budaya pop menawarkan keragaman ketika ia diinterpretasi ulang oleh masyarakat yang berbeda dilain tempat. Kedua, budaya pop itu sendiri dipandang sebagai sekumpulan genre, teks, citra yang bermacam-macam dan bervariasi yang dapat ditemui dibebagai media, sehingga sukar sebuah budaya pop dapat dipahami dalam kriteria homogenitas dan standarisasi baku. Ada beberapa macam-macam bentuk budaya pop, diantaranya sebagai berikut:1) Televisi, 2) Fiksi, 3) Film, 4) Surat Kabar dan Majalah, 5) Musik Pop dan 6) Konsumsi dalam kehidupan sehari-hari. 


\subsection{Empat Ideologi Budaya Indonesia}

Empat ideologi budaya yang ada di Indonesia yaitu budaya agama, budaya lokal, budaya nasional dan budaya pop.Dalam perkembangannya, keempat macam budaya tersebut adakalanya saling berseberangan, budaya agama cenderung orientasinya kepada pascaduniawi seringkali berseberangan dengan budaya pop yang kebanyakan berorientasi kepada duniawi.Sehingga kemunculan Imam Mahdi,pemimpin pasca-duniawi yang muncul diera milenium ini tidak terpopulerkan, padahal sosok ini dipandang oleh 3 agama besar didunia sebagai sosok sang juru selamat diakhir jaman ini untuk di imani umat yang diperintahkan Nabi-Rasulullah Muhammad SAW dalam Sabdanya: Jika kamu melihat yang demikian itu berbai'atlah, sesungguhnya ialah Mahdi, walaupun kalian harus merangkak diatas salju (HR.Abu Daud).Karena perintah Rasulullah ini tidak dijalankan maka terjadilah huru hara akhir zaman (murka Allah) berupa bala bencana alam termasuk seperti sekarang ini bencana wabah Virus Corona (C-19) melanda dunia, sebagaimana menimpa kaum Ad dalam Firman Allah:Dan bahwasanya Dia telah membinasakan Ad yang pertama (QS, AnNajm:50).Budaya lokal dan budaya nasional juga sering tergerus identitasnya oleh budaya pop.

Dari keempat ideologi budaya tersebut, budaya nasional paling lemah, terbukti dengan adanya kasus-kasus di negara ini, seringkali terjadi konflik massa mengatasnamakan etnis dan agama. Namun diantara keempat budaya tersebut, sebagai anak kandung dari kapitalisme. Budaya pop yang paling bisa merasuk kepada ideologi-ideologi tersebut diatas. Meskipun dalam perjalanannya hadangan dari budaya agama, budaya lokal, dan budaya nasional selalu ada.

\section{Metode Penelitian}

Peneltian ini mengguanakan metode kualitatif sebagai prosedur penelitian, menghasilkan data-data naratif-deskriptif berupa cerita yang disajikan secara tulisan maupun lisan yang bersumber dari penikmat Budaya Pop. Pendekatan yang digunakan adalah metode deskriptif dengan pendekatan kualitatif.Pendekatan deskriptif karena penelitiannya memusatkan pemecahan pada masalah yang aktual, Surakhmad (2005:139), sedangkan Sugiyono (2006:216) mengemukakan bahwa: Penggunaan kualitatif karena penelitian berangkat dari 
kasus tertentu yang berada pada objek penelitian".Berdasarkan kedua pendapat diatas maka penelitian ini merupakan studi kasus yang memfokuskan pada objek penelitaian pada kasus yang terjadi di Indonesia yang populer.Walaupun demikian, penelitian ini diperlukan untuk lebih menggambarkan situasi dan kondisi objek penelitian. Menurut Biklen \& Bogdan (1990:30-34) Penelitian Kualitatif memiliki karakteristik sebagai berikut:

1) Mempunyai latar alami dengan sumber data langsung dan peristiwanya sebagai instrumen utama. 2) Bersifat deskriptif. 3) Memperhatikan proses ketimbang hasil.

4) Analisis data secara induktif. 5) Mengutamakan makna.Dari lima karakteristik lebih dikembangkan lagi oleh Nasution (1992:19) sebagai berikut: 1) Penelitian dilakukan dalam “natural setting”. 2) Penelitian sebagai "human instrument”. 3) Sangat deskriptif. 5) Mementingkan proses maupun produk. 6) Mencari makna. 7) Mengutanakan data langsung atau "first hand”. 8) Melakukan “transgulasi”. 9) Menonjolkan konteks.

10) Peneliti berkedudukan sama dengan orang yang diteliti. 11) Mengutamakan pandangan "emie". 12) Mengadakan verifikasi. 13) Menggunakan sampling yang purpositif.14) Menggunakan "audit trail”. 15) Melakukan partisipasi tanpa mengganggu. 16) Mengadakan analisis sejak awal. 17) Disain yang emergent.

Berdasarkan dua pendapat diatas, maka lebih memperjelas atau memperkuat bahwa metode yang digunakna dalam penelitian ini adalah metode deskriptif yang mengungkap kenyataan yang ada dilapangan serta dapat dipahami secara mendalam, sehingga pada akhirnya dapat diperoleh temuan penelitian.Penelitian yang menggunakan pendekatan kualitatif adalah sesuatu proses yang dimulai dari melihat, mengkaji dan menganalisis suatu fenomena dengan sedalam-dalamnya serta menemukan makna yang sangat berarti didalamnya.Untuk memperoleh karakteristik yang sesuai dan makna yang diharapkan dapat dikemukakan, maka teknik pengumpulan data yang digunakan melalui beberapa studi atau cara yaitu : Observasi, wawancara dan dokumentasi.

\section{Hasil Penelitian}

Islam mengatur setiap aspek dalam kehidupan mulai dari hal-hal yang remeh hingga perkara yang kompleks. Dari urusan buang air kecil sampai urusan mengatur negara. Firman Allah SWT:"Sesungguhnya telah Kami muliakan anak-anak Adam, Kami angkut mereka di 
daratan dan di lautan, Kami beri mereka rezki dari yang baik-baik dan Kami lebihkan mereka dengan kelebihan yang sempurna atas kebanyakan makhluk yang telah Kami ciptakan”.

\section{Demam Korean style (K-Pop)}

Demam Korean style (K-Pop) bahaya laten bagi umat Islam. Sebabnya Korean style, selain mencemari tradisi budaya Indonesia yang santun, juga merusak akhlak dan mendonstruksi prinsip-prinsip ajaran ahklak Islam.Allah SWT telah menjadikan mereka sebagai mahluk yang paling mulia dibanding mahluk lainnya, seharusnya mereka menjaga keutuhan martabatnya sebagai manusia tidaklah boleh terlalu berlebih-lebihan dalam pergaulan tidak melanggar norma agama.Kehidupan borjuistis K-Pop, semangat hedonis dan matrealistis dalam narasi sinetronnya, serta pakian aurat dalam model busana artisnya, menggeser pola laku para penggemarnya, menjadi trend besar-besaran secara masal.Telah tampak pada kaum melenial muslim sekarang, dari penampilan hingga mindset, akan berubah ala Korean style. Seolah terhipnotis performance Koreanistis, setiap model yang datang dari mereka dianggap positif dan selalu di up-date oleh mereka. Seperti minuman Wine Korean, bir Korea dikatakan baik meski memabukkan, padahal diharamkan dalam agama.Korean Style bisa mengikis akhlak umat, juga akan mendekonstruksi keimanan umat. Hal ini disebabkan karena adanya upaya niru-niru artis idola K-Pop, menyebabkan orang Islam menjadi munafik keluar dari akhlak Islami yang sesungguhnya. Korean style produk globalisasi bidang Fun atau hiburan, dapat kian mengikis akhlak umat Islam secara global.Padahal yang harus menjadi acuan idola adalah akhlak Rasulullah Nabi Muhammad SAW sebagai mana sabdanya: Kami diutus untuk menyempurnakan akhlak (HR.Buhori dan Muslim).

\section{Dampak Budaya Pop}

Dampak yang disebabkan oleh adanya Budaya Pop ada dua dampak, hal utama dalam budaya populer : Pertama, suatu budaya pop memiliki karakter negatif karena dia diproduksi secara massal hanya untuk memenuhi kepuasan si pendengar atau si pengguna yang membayarnya.Alasan komersial, karakter negatif dari produk kebudayaan tidak disaring, malah cenderung dilanggengkan. Mereka berkata bisnis adalah bisnis.

Kedua, budaya pop juga memiliki akibat dan pengaruh yang negatif. Misalnya, ketika kita menonton televisi atau video, kita seringkali terpengaruh oleh model-model yang ada pada film tersebut, intinya produk gaya hidup kita terpengaruhi atau dirasuki oleh gaya hidup orang yang berbeda dari yang kita tonton. 
Dampak negatif dari budaya pop juga cenderung membuat kita menjadi lebih hedonistik. Iklan menjadi sarana dalam melancarkan jalannya kapitalisme, tidak jarang pemuda di Indonesia menjadi korban iklan. Marcuse berpendapat bahwa, pengiklanan mendorong kebutuhan palsu misalnya, keinginan untuk menjadi jenis orang tertentu, mengenakan tipe pakaian tertentu, memakan macam-macam makanan tertentu, meminum minuman khusus, menggunakan macam-macam produk khusus dan seterusnya.

Dalam budaya pop juga ada dampak positif, seperti dalam televisi yang menayangkan acara-acara yang bermanfaat, dan dapat diaplikasikan dalam kehidupan sharai-hari. Dengan adanya budaya pop meskipun dipandang mempunyai dampak yang negatif, tidak akan negativ lagi apabila disikapi secara bijak dengan baik. Semuanya kembali lagi kepada kita, bagaimana cara kita untuk menysikapinya.

\section{Kesimpulan}

Dapat kita ambil kesimpulan dari ajaran agama kita bahwa syarieeat Al Quran bukan hanya mengatur kehidupan dan berbagai hal yang di luar diri kita, bahkan syar'at Al Quran juga mengatur segala hal yang berkaitan dengan diri kita, dimulai dari makanan, penampilan, perilaku, dan lain-lain. Ini semua bertujuan agar umat Islam menjadi insan dan mahluk yang paling bermutu dibanding dengan insan dan mahluk lainnya.Budaya pop ini merupakan budaya pertarungan makna dimana segala macam makna budaya pop bertarung memperebutkan hati massa. Dan sekarang ini, model praktis dan pemikiran pragmatis mulai berkembang dalam pertempuran makna tersebut. Budaya pop yang sekarang ini berkembang pesat, menumbuhkembangkan juga determinasi popular budaya massa yang sulit dikontrol atau disaring. Budaya pop dapat diartikan sebagai sesuatu yang sudah berkembang kemudian menjadi kebiasaan umum dan disukai oleh banyak orang.Macam-macam bentuk budaya pop, diantaranya:Televisi, Fiksi, Film, Surat Kabar dan Majalah, musik pop dan konsumsi dalam kehidupan sehari-hari.Dua hal yang utama dalam budaya pop ini, yaitu dampak positif dan dampak negatif. Semua itu kembali lagi kepada diri kita bagaimana cara kita bisa menyikapinya.

\section{Saran}

Dengan materi "Budaya Pop “, marilah kita memahami makna filosofi Budaya Pop guna untuk filterisasi atau menyaring budaya pop yang berkembang di era modernitas ini. Agar tercipta masyarakat yang berbudi luhur dan bermoralitas tinggi. 


\section{Sumber:}

.-Ridho Nur Wahyu (2020), 5 Budaya Indonesia yang Terkenal di Dunia,Google.Com .HIS Travel,(2020),12 Kebudayaan dan Tradisi Indonesia Yang Mendunia, Google .Com .Yulia Melani (2015),101 Kebudayaan Sunda Yang Populer di Dunia,Google .com -Wikipedia.org,(2020),Wayang Kulit, Goolge.com

-Yaya Badriya, (2016),12 Budaya Indonesia yang Mendunia, Goole.com

-Naufal,Diki.A-L.Fajriyah,(2016),Makalah Budaya Populer, DIY):UIN Sunan Kalijaga

-Wikipedia Indonesia (2020),Budaya Populer,Google.Com

-Tim Kemenristek-BRIN,(2020),Panduan Penelitian \& Pengabdian Kepada Masyarakat,edisi XIII

-Tim FISIP Universitas Al-Ghifari,2020, makalah Lokakarya Kurikulum 2020, kampus merdeka, Kemendikbud RI

-Prof.Dr.Koencoro Ningrat,1988,Manusia dan Kebudyaan,penerbit Jambatan.

-Tim Dosen IBD/ISBD, 2020, materi kuliah IBD/IBSD, Unfari dan Uninus -PB,Aquarini Priyatna (2016),Kajbud Feminis,Tubuh, Sastra dan Budaya Pop, DIY, Jalasutra. -A.M.Baqir Al-Majlisi (2009), Riwayat Imam Mahdi Pemimpin Akhir Zaman dan Penegak Keadilan di Muka Bumi, Jakarta, Lentera. 